\title{
HUBUNGAN MOTIVASI KERJA DAN KEMAMPUAN PENGUASAAN MATERI DENGAN KINERJA GURU DI KABUPATEN PANDEGLANG
}

\author{
S a m u d i \\ STAI La Tansa Mashiro Rangkasbitung \\ Jln. Soekarno-Hatta Pasirjati Rangkasbitung Lebak Banten, Indonesia \\ samudidr.banten@gmail.com
}

\begin{abstract}
ABSTRAK
Penelitian ini dilatar belakangi di antaranya oleh motivasi kerja guru aqidah akhlak yang belum memenuhi harapan semua pihak, guru masih terbatas dalam kemampuan penguasaan materi bidang studi aqidah akhlak dan kinerja guru masih belum maksimal dalam proses pembelajaran terhadap siswa.

Penelitian ini bertujuan untuk mengetahui, menganalisis dan merumuskan korelasi antara motivasi kerja dan kemampuan penguasaan materi secara bersama-sama dengan kinerja guru pada bidang studi aqidah akhlak. Lokasi penelitian ini pada Madrasah Tsanawiyah di Kabupaten Pandeglang Banten.

Penelitian ini menggunakan metode survey dengan analisis data korelasional. Sampel penelitian ini sebanyak 35 orang guru, sedangkan pengumpulan datanya menggunakan observasi, wawancara, angket dan tes.

Hasil temuan penelitian ini yaitu terdapat korelasi positif dan signifikan antara motivasi kerja dan kemampuan penguasaan materi secara bersama-sama dengan kinerja guru dengan koefisien korelasi ganda yaitu sebesar 0,882. Artinya bahwa motivasi kerja dan kemampuan penguasaan materi telah memberikan dukungan positif dan signifikan terhadap kinerja guru.

Kesimpulan bahwa semakin tinggi motivasi kerja yang meliputi; tanggung jawab, prestasi, pengembangan diri dan kemandirian dan kemampuan penguasaan materi yang meliputi kognitif, afektif dan psikomotirik, maka semakin tinggi kinerja guru yang meliputi; perencanaan dalam pengajaran, pengelolaan kelas, pembelajaran dan evaluasi.
\end{abstract}

\section{Kata Kunci: Motivasi Kerja, Kemampuan Penguasaan Materi, Kinerja Guru}

\begin{abstract}
This research is motivated, among others, by the work motivation of the aqidah akhlak teacher who has not met the expectations of all parties, the teacher is still limited in the ability to master the subject matter in the field of aqidah morals and the teacher's performance is still not optimal in the learning process for students.

This study aims to determine, analyze and formulate the correlation between work motivation and the ability to master the material together with the performance of teachers in the field of study aqidah morals. The location of this research is at Madrasah Tsanawiyah in Pandeglang, Banten.
\end{abstract}

1 | Almarhalah | JurnalPendidikan Islam 
This study used a survey method with correlational data analysis. The research sample consisted of 35 teachers, while data collection used observation, interviews, questionnaires and tests.

The findings of this study are that there is a positive and significant correlation between work motivation and the ability to master the material together with teacher performance with a multiple correlation coefficient of 0.882. This means that work motivation and mastery of material have provided positive and significant support to teacher performance.

The conclusion is that the higher the work motivation which includes; responsibility, achievement, self-development and independence and the ability to master the material which includes cognitive, affective and psychomotor, the higher the teacher's performance which includes; planning in teaching, classroom management, learning and evaluation.

\section{Keywords: Work Motivation, Material Mastery Ability, Teacher Performance}

\section{Pendahuluan}

Untuk penyelenggaraan pendidikan di sekolah dengan baik selain diperlukan perangkat kurikulum yang baik, ditentukan juga oleh adanya seorang guru yang baik dalam melaksanakan tugasnya sebagai pendidik dan pengajar. Guru merupakan salah satu faktor eksternal yang dapat mempengaruhi hasil proses belajar siswa dan memiliki peranan yang sangat menentukan dalam menghasilkan prestasi belajar siswa. Mengajar di depan kelas merupakan perwujudan interaksi dalam proses komunikasi, di mana guru sebagai pemegang kunci sangat menentukan keberhasilan belajar siswa (Wijaya dan Rusyan, 2002). Sementara itu, pelaksanaan kurkikulum hampir seluruhnya bergantung kepada kreativitas, kecakapan, kesanggupan dan ketekunan tenaga pengajar (Sukmadinata, 2009).

Mengingat guru pekerjaannya bergerak pada bidang pendidikan dan pengajaran, maka tujuan yang ingin dicapai adalah tujuan dari pendidikan dan pengajaran itu sendiri. Dengan demikian kinerja seorang guru tersebut dapat terlihat dan dibuktikan dari perbuatan atau kegiatannya mengajar di dalam kelas. Sedangkan untuk melahirkan kinerja seorang guru dalam tugasnya, maka sangat dibutuhkan adanya beberapa faktor yang mendukungnya, di antaranya terdapatnya motivasi kerja dan mempunyai kemampuan penguasaan materi pelajaran yang baik.

Kinerja guru merupakan suatu pencapaian tujuan dari guru itu sendiri seperti pengambilan keputusan pada waktu mengajar di kelas, adanya tujuan pendidikan dan pengajaran dari sekolah dan juga rasa tanggungjawab dari atas kelancaran proses belajar mengajar terhadap peserta didik. Kinerja guru yang baik terlihat dari hasil yang diperoleh dari penilaian prestasi belajar siswa (Glasman, 1986). Demikian juga kinerja guru dapat terlihat juga dalam kepuasaan siswa dan orang tua, perilaku sosial dan kehadiran guru.

2 | Almarhalah | JurnalPendidikan Islam 
Motivasi kerja merupakan salah satu faktor internal yang ada pada seseorang untuk mendorong melaksanakan tugasnya dengan baik. Motivasi kerja merupakan sesuatu yang menimbulkan semangat atau dorongan untuk bekerja (Anoraga, 2005). Motivasi kerja dapat dikatakan juga sebagai pendorong semangat kerja. Kuat lemahnya motivasi kerja seseorang ikut menentukan produktifitas, prestasi dan profesionalisme kinerjanya. Motivasi kerja merupakan kumpulan yang akan membuat stabil dari ambisi, cita-cita, harapan, norma dan kebutuhan mengenai isi pekerjaan, syarat-syarat kerja dan kesadaran kerja yang memberikan ciri khas kepada seseorang tertentu. Hoogendoorn (1989).

Selain itu, motivasi kerja merupakan suatu dorongan kerja yang ditimbulkan dari dalam dan luar individu untuk melakukan tugas atau kegiatan dalam rangka pemenuhan kebutuhan hidupnya. Sementara itu motivasi kerja guru merupakan sesuatu yang menimbulkan semangat atau dorongan kepada guru untuk bekerja dengan sebaik-baiknya. Dengan kata lain, motivasi kerja guru merupakan suatu dorongan yang bersumber dari dalam dan luar diri guru yang dapat menimbulkan kinerja guru dalam melakukan pendidikan dan pembelajaran secara efektif dan efesien. Oleh karenanya seorang guru yang motivasi kerjanya tinggi ditandai antara lain memiliki tanggung jawab dalam pekerjaannya, selalu berusaha untuk memperoleh kemajuan dan selalu berusaha mengembangkan profesinya.

Motivasi kerja guru yang tinggi merupakan persyaratan penting bagi terwujudnya suatu kinerja guru yang baik dalam proses belajar mengajar di sekolah. Oleh sebab itu apabila seorang guru mengalami ketidakpuasan kerja, maka penampilannya akan menurun di bawah kinerja yang standar, karenanya motivasi kerja guru memiliki hubungan langsung dengan kinerja guru. Motivasi kerja guru dapat menentukan tingkat kinerja guru dalam menjalankan tugasnya, hal ini dapat tercermin pada konsistensi, frekuensi, intensitas, pengorbanan, upaya menghindar dari kegagalan serta pencapaian tujuan secara maksimal.

Salah satu faktor yang dapat menentukan kinerja guru dalam melaksanakan proses belajar mengajar di kelas yaitu adanya kemampuan penguasaan materi bidang studi yang menjadi tanggung jawab seorang guru tersebut. Kemampuan penguasaan materi bidang studi merupakan kesanggupan, kecakapan, keahlian, keterampilan dan kekuatan dari seorang guru dalam melakukan suatu pengajaran materi bidang studi yang diajarkannya.

Di dunia pendidikan kemampuan penguasaan materi oleh seorang guru, atau disebut juga dengan kompetensi guru merupakan adanya sikap profesionalisme guru terhadap materi bidang studi yang menjadi tanggung jawabnya, yang meliputi; ranah pengetahuan, ranah sikap dan ranah keterampilan. Salah satu bentuk keberhasilan pendidikan di sekolah adalah dengan adanya kemampuan penguasaan materi ajar oleh seorang guru yang telah ditetapkan dalam kurikulum operasional. Seorang guru harus menguasai ilmu pengetahuan atau bahan ajar yang diberikan, dan seorang guru harus siap dengan bahan ajar yang diatur dengan sistematis, sesuai dengan satuan acara pengajaran yang telah ditetapkan (Sudjana, 2010). 
Untuk melahirkan kinerja guru, maka seorang guru dituntut dengan sejumlah persayaratan, di antaranya yaitu memiliki kualifikasi pendidikan profesi yang memadai, memiliki kompetensi keilmuan sesuai dengan bidang studi yang ditekuninya, memiliki kemampuan berkomunikasi yang baik dengan anak didiknya, mempunyai jiwa kreatif dan produktif, memiliki etos kerja dan komitmen tinggi terhadap profesinya dan selalu melakukan pengembangan diri secara terus menerus melalui organisasi, profesi, internet, buku seminar, dan semacamnya (Sidi, 2001).

Kemampuan penguasaan materi bidang studi oleh seorang guru merupakan salah satu bentuk adanya sikap profesionalisme guru. Sedangkan profesionalisme guru itu sendiri merupakan kondisi, arah, nilai, tujuan dan kualitas suatu keahlian dan kewenangan dalam bidang pendidikan dan pengajaran yang berkaitan dengan pekerjaan seseorang guru yang menjadi mata pencahariannya (Wijaya dan Rusyan, 2002). Dari kontek ini dapat jelaskan bahwa profesionalisme guru merupakan tuntutan dari seorang guru untuk menjalankan tugasnya sebagai pendidik dan pengajar dalam proses belajar mengajar di sekolah dengan kesungguhan dan komitmen serta tanggung jawab yang tinggi sebagai wujud nyata menjungjung tinggi profesinya tersebut.

Guru profesional merupakan orang yang terdidik dan terlatih dengan baik serta kaya dibidangnya. Dengan demikian guru yang professional merupakan guru yang memiliki kemampuan penguasaan dan keahlian khusus pada materi bidang keguruan dan bidang pendidikan yang diajarkannya, sehingga guru itu mampu melakukan tugas dan fungsinya sebagai guru dengan kemapuan maksimal (Usman, 2004). Dengan kata lain, kemampuan penguasaan materi bidang studi Aqidah Akhlak oleh seorang guru merupakan adanya kemampuan penguasaan kecakapan, keterampilan dan keahlian yang harus dimiliki oleh seorang guru terhadap bahan ajar bidang studi Aqidah Akhlak yang menjadi tanggung jawabnya.

Pendidikan bidang studi Aqidah Akhlak pada penelitian ini merupakan bidang studi yang terdapat dalam jenjang Madrasah Tsanawiyah yang merupakan sub mata pelajaran pada jenjang pendidikan dasar yang membahas ajaran agama Islam dalam segi aqidah dan akhlak. Mata pelajaran Aqidah Akhlak juga merupakan bagian dari mata pelajaran pendidikan agama Islam yang memberikan bimbingan kepada siswa agar memahami, menghayati, meyakini kebenaran ajaran Islam, serta bersedia mengamalkannya dalam kehidupan seharihari.

Materi pokok yang terdapat dari bidang studi Aqidah Akhlak ini meliputi: hubungan manusia dengan Allah, hubungan manusia dengan manusia, dan hubungan manusia dengan alam sekitarnya. Kemampuan penguasaan materi ketiga materi pokok mata pelajaran Aqidah Akhlak ini menjadi indikator tercapainya kinerja seorang guru dalam proses belajar mengajar terhadap siswanya.

Berdasarkan dari beberapa uraian tersebut, ternyata banyak sekali faktor yang dapat mempengaruhi kinerja guru dalam proses belajar mengajar siswa di kelas, terutama dalam menyampaikan bidang studi Aqidah Akhlak, di antaranya

4 | Almarhalah | JurnalPendidikan Islam 
adalah faktor motivasi kerja dan kemampuan penguasaan materi bidang studi. Oleh karena begitu pentingnya keberadaan guru dalam suatu proses belajar mengajar di sekolah, maka kinerja guru dalam hubungannya dengan motivasi kinerja dan kemampuan penguasaan materi bidang studi Aqidah Akhlak menjadi sangat menarik untuk diteliti.

Perumusan masalah dalam penelitian ini adalah apakah terdapat hubungan antara motivasi kerja dan kemampuan penguasaan materi dengan kinerja guru pada mata pelajaran Aqidah Akhlak ?.

\section{TINJAUAN PUSTAKA}

\section{Motivasi Kerja}

Motivasi adalah merupakan kekuatan yang mendorong seseorang melakukan sesuatu untuk mencapai tujuan, dan kekuatan-kekuatan itu didasarkan kepada rangsangan oleh adanya berbagai macam kebutuhan, yaitu keinginan yang hendak dipenuhi, tingkah laku, tujuan dan umpan balik (Hellriegel, 1979). Motivasi merupakan dorongan yang terdapat dalam diri seseorang untuk berusaha mengadakan perubahan tingkah laku yang lebih baik dalam memenuhi kebutuhannya (Winkel, 2014).

Dalam penjelasan lainnya, motivasi adalah suatu pernyataan yang kompleks di dalam suatu organisme yang mengarahkan tingkah laku terhadap suatu tujuan (goal) atau perangsang (incentive) (Purwanto, 2007). Motivasi adalah dorongan dasar yang menggerakan seseorang bertingkah laku. Dorongan ini berada pada diri seseorang yang menggerakan untuk melakukan sesuatu yang sesuai dengan dorongan dalam dirinya. Oleh karena itu perbuatan seseorang yang didasarkan atas motivasi tertentu mengandung tema sesuai dengan motivasi yang mendasarinya (Sopyan dan Uno, 2004). Motivasi adalah suatu proses untuk menggiatkan motif-motif menjadi perbuatan atau tingkah laku untuk memenuhi kebutuhan dan mencapai tujuan, atau keadaan dan kesiapan dalam diri individu yang mendorong tingkah lakunya untuk berbuat sesuatu dalam mencapai tujuan tertentu (Usman, 2002).

Robbins dan Coulter (2012) menjelaskan bahwa motivasi adalah sebagai kesediaan untuk mengeluarkan tingkat upaya yang tinggi untuk tujuan organisasi, yang dikondisikan oleh kemampuan upaya itu dalam memenuhi beberapa kebutuhan individual. Shafter dan Shoben (1956) mengatakan bahwa motivasi adalah sebagi energi vital atau daya dorong hidup yang merangsang seseorang untuk melakukan suatu aktivitas. Ferguson (1987) mendefinisikan motivasi yaitu "Motivation refers to internal states of an organism that lead to the instigation, pesistence, energy, or direction of behavior". Sedangkan Crider sebagaimana yang dikuti oleh Lavau (1999) berpendapat: "Motivation can be defined as the desires, needs, and interests that aouse or activate an organism an direct in toward a specific goal". Atkison (1983) mendefinisikan motivasi sebagai "the contemporary (immediate) influences on direction, vigor and persistences of action'. 
Sementara itu James (1995) menyatakan bahwa motivasi sebagai "how behavior get started, is energized, is sustained, is directed, is stoped, and what kind of subjective reaction is present in the organism while all this is going on". Menurut Jerald Greenberg (2008) terdapat tiga elemen kunci dalam motivasi yaitu "motivation as the set of processes that arouse, direct, and maintain human behavior toward attaining some goal.

Dari penjelasan definisi motivasi tersebut di atas dapat diketahui bahwa motivasi itu dapat terjadi bila seseorang mempunyai keinginan dan kemauan untuk melakukan suatu kegiatan atau tindakan dalam rangka mencapai tujuan tertentu, yang dijelaskan dalam gambar/bagan berikut ini:

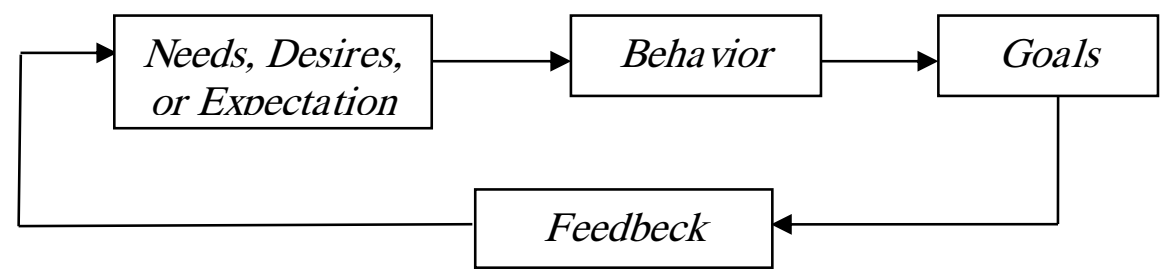

Wayne K. Hoy dan Cecil G. Miskel (Hamzah B. Uno, 2008)

Beberapa penjelasan tersebut di atas, dapat dikemukakan bahwa motivasi adalah bidang pengkajian manajemen yang banyak melibatkan aspek-aspek psikologis, karena dengan motivasi lebih banyak menjelaskan terjadinya perilaku orang-orang yang didorong oleh kondisi psikis yang ada pada diri mereka masingmasing sifatnya halnya dorongan untuk kesediaan bekerja dengan baik, kesadaran dalam menunaikan tugas, rasa tanggung jawab dan upaya meningkatkan keberhasilan kerja.

Sementara itu, motivasi kerja adalah kumpulan yang akan stabil dari ambisi, cita-cita, harapan, norma dan kebutuhan mengenai isi pekerjaan, syaratsyarat kerja dan kesadaran kerja yang memberikan ciri khas kepada seseorang tertentu (Hoogendoorn, 1989). Dalam redaksi lain bahwa motivasi kerja adalah sesuatu yang menimbulkan dorongan atau semangat kerja.

Dari beberapa penjelasan di atas, dapat diambil suatu konklusi bahwa motivasi kerja adalah suatu dorongan kerja yang ditimbulkan dari faktor internal dan ekternal individu untuk melakukan tugas atau kegiatan dalam pemenuhan kebutuhan hidupnya. Dengan kata lain, bahwa motivasi kerja adalah merupakan salah satu faktor yang turut menentukan kinerja seseorang, besar kecilnya pengaruh motivasi pada kinerja seseorang tergantung pada seberapa banyak intensitas motivasi yang diberikan. Sedangkan yang dimaksud dengan motivasi kerja guru adalah suatu proses yang dilakukan untuk menggerakkan guru agar perilaku mereka dapat di arahkan pada upaya-upaya yang nyata untuk mencapai tujuan yang telah ditetapkan.

Motivasi terbagi kepada dua jenis, yaitu: 1) Motivasi instrinsik adalah motivasi yang datang dalam diri seseorang, misalnya pegawai melakukan suatu kegiatan karena ingin menguasai sesuatu keterampilan tertentu yang dipandang akan berguna dengan pekerjaannya dan 2) Motivasi ektrinsik adalah motivasi yang berasal dari lingkungan di luar seseorang, misalnya pegawai bekerja ingin

6 | Almarhalah | JurnalPendidikan Islam 
mendapatkan pujian atau hadiah dari pimpinannya (Davis dan Newstrom, 1995). Sedangkan teori motivasi dia ntaranya yaitu ; teori kebutuhan dari Maslow, teori dua factor dari Herzberg, teori prestasi dari Mc Clelland, teori X dan Y dari Mc Gregor dan teori harapan dari Vroom (Adikoesoemo, 2002).

Sementara itu, motivasi kerja individu dalam melaksanakan tugas pekerjaanya dipengaruhi oleh beberapa faktor, yaitu: 1) sikap individu terhadap obyek, 2) kepercayaan, 3) nilai-nilai, 4) kebutuhan dan 5) tujuan, yang dapat digambarkan seperti di bawah ini:

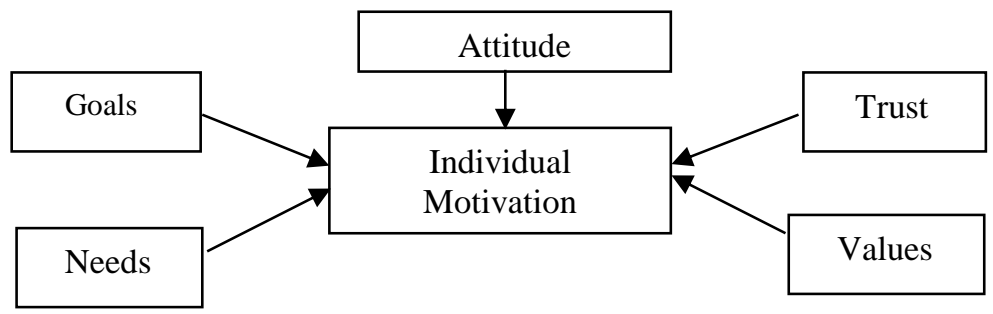

Hugh J. Arnold and Daniel C. Feldman (1986).

Dalam penjelasan lain, motivasi kerja dapat dipengaruhi juga oleh faktorfaktor yaitu: kebutuhan kelangsungan hidup, kebutuhan keamanan, kebutuhan berkelompok, kebutuhan penghargaan, kebutuhan kebebasan kebutuhan kecakapan dan keberhasilan (Kenneth, 1992). Sedangkan hal lain yang dapat meningkatkan motivasi kerja yaitu; perencanaan insentif, job inrichment, dan managemen berdasarkan sasaran (Kenneth, 1992). Sementara itu karakteristik yang dapat dijadikan indikator motivasi kerja yaitu: pengharapan, penghargaan, prestasi, hubungan kerja, pengawasan, pengembangan diri dan administrasi dan kebijakan pemimpin (Matahari, 2000).

Dari beberapa penjelasan di atas, dapat diambil suatu konklusi bahwa faktor yang mempengaruhi motivasi kerja adalah sesuatu yang mendorong, merangsang seseorang sehingga berkeinginan melakukan tindakan atau kerja dalam rangka mencapai tujaun organisasi, atau merupakan daya dorong atau kekuatan yang memberikan semangat berinpirasi pada seseorang untuk mengambil tindakan yang mengarah kepada pencapaian kebutuhan sehingga memberikan kepuasan terhadap tujuan yang hendak dicapai, baik disadari maupun tidak disadari.

Al-Qur' an yang menjelaskan tentang motivasi kerja di antaranya yaitu:

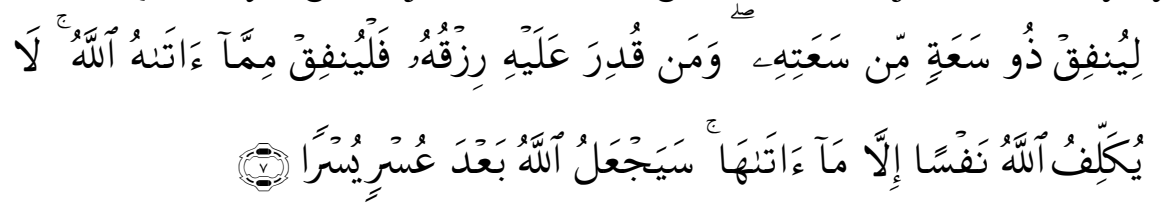

Artinya: "Hendaklah orang yang mampu memberi nafkah menurut kemampuannya. Dan orang yang disempitkan rezkinya hendaklah memberi nafkah dari harta yang diberikan Allah kepadanya. Allah tidak memikulkan beban kepada seseorang melainkan sekedar apa yang Allah berikan kepadanya. Allah kelak akan memberikan kelapangan sesudah kesempitan" (QS. Ath- Thalaaq: 7). 
Demikian juga dalam Hadits Rasulullah SAW dijelaskan tentang semangat motivasi dalam melakukan pekerjaan, yaitu:

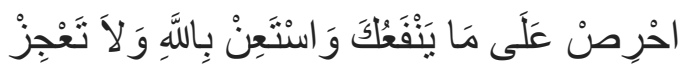

Artinya: "Bersemangatlah melakukan hal yang bermanfaat untukmu dan meminta tolonglah pada Allah, serta janganlah engkau malas”(HR. Muslim).

\section{Kemampuan Penguasaan Materi}

Kata "kemampuan" mengandung makna kesanggupan melakukan sesuatu, kecakapan melakukan sesuatu, atau kekuatan melakukan sesuatu (Purwadarminta, 2015). Dalam Bahasa Inggris kata "kemampuan" disebut dengan istilah "competency". Sedangkan kata kompetensi menurut Broke dan Stone (Usman, 2001) yaitu "Descriptive of qualitative natur of teacher's behaviour appears to be entirely meaningful". Mc Leod menjelaskan kemampuan adalah "The state of being legally competent or qualified" yaitu kewenangan atau memenuhi syari'at menurut hukum (Syah, 2002). Kemampuan (competency) ialah kemampuan dan ciri-ciri yang ada pada diri guru dan yang dapat mengembangkan kondisi belajar (Dendasurono, 2008).

Sementara itu, kemampuan penguasaan materi yang dimaksudkan dalam penelitian ini adalah kesanggupan, kecakapan, kekuatan, kewenangan dan kekuasan dari seorang guru dalam menyampaikan materi pelajaran Aqidah Akhlak dalam proses belajar mengajar di kelas yang menjadi tanggung jawabnya dengan ruang lingkup materi; hubungan manusia dengan Tuhan, hubungan manusia dengan manusia dan hubungan manusia dengan lingkungannya (Depag, 2003).

Kemampuan atau kompetensi profesi guru dapat digolongkan menjadi tiga bagian, yaitu : 1) kompetensi pengetahuan (knowledge competencies) yang menekankan pada aspek pengetahuan guru tentang kemampuan penguasaan materi, 2) kompetensi penampilan perbuatan (performance competencies) yang menekankan pada aspek perilaku atau kinerja guru yang dapat diamati, 3) kompetensi akibat (consequence competencies) yang menekankan pada aspek hasil belajar yang merupakan akibat dari kompetensi pengetahuan dan penampilan (Soedarminto, 2008).

Cooper (2009) menjelaskan bahwa dalam melaksanakan pembelajaran, seorang guru dituntut harus mempunyai kemampuan, yaitu : 1) menguasai materi bidang studi yang akan diajarkannya, 2) mempunyai pengetahuan tentang belajar tingkah laku manusia, 3) mempunyai sikap yang tepat tentang diri sendiri, sekolah, teman sejawat, dan 4) mempunyai keterampilan teknik dalam mengajar. Dengan demikian menurut Cooper bahwa seorang guru harus memiliki kemampuan, khususnya kemampuan professional yaitu kemampuan penguasaan materi sebagai syarat utama sebagai seorang guru.

Dalam pandangan Islam, dijelaskan bahwa segala sesuatu kegiatan atau pekerjaan apabila ingin mencapai atau mendapatkan keberhasilan yang maksimal, maka harus dikerjakan atau diserahkan kepada orang yang menguasai keilmuan

8 | Almarhalah | Jurnal Pendidikan Islam 
pekerjaan tersebut atau diserahkan kepada ahlinya. Hal ini sebagaimana alQur'an surat.

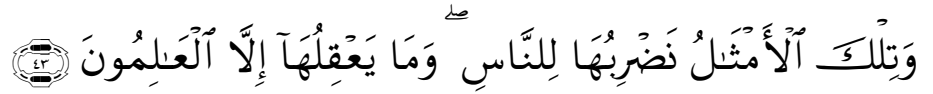

Artinya: "dan perumpamaan-perumpamaan ini Kami buat untuk manusia; dan tiada yang memahaminya kecuali orang-orang yang berilmu” (QS. Al-Ankabut:43).

Demikian juga dalam Hadits Rasululullah SAW yang menjelaskan tentang pekerjaan yang harus dikerjakan sesuai dengan ahlinya, yaitu:

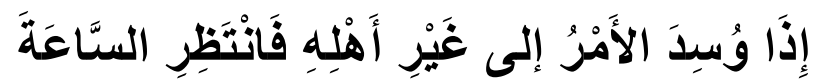

Artinya: "Apabila suatu perkara diserahkan kepada yang bukan ahlinya maka tunggulah kehancurannya (HR. Bukhari)

\section{Kinerja Guru}

Richard L. Hughes et. al, (2009) mendefinisikan kinerja yaitu "performance, on other hands, concerns those behaviors directed toward the organization's mission or goals or the products and services resulting from those behaviors. Aldag dan Steams (1987) berpendapat bahwa kinerja adalah pencapaian tujuan pada banyak organisasi. Kinerja merupakan seperangkat hasil yang dicapai dan merujuk pada tindakan pencapaian serta pelaksanaan suatu pekerjaan yang diminta (Stolovich dan Keeps, 1992).

Guru sebagaimana dijelaskan dalam UU No. 14 tahun 2005 adalah pendidik profesional dengan tugas utama mendidik, mengajar, membimbing, mengarahkan, melatih, menilai dan mengevaluasi peserta didik pada pendidikan anak usia dini diluar jalur pendidikan formal, pendidikan dasar, dan pendidikan menengah. Sedangkan dalam UU No. 20 tahun 2003 dijelaskan bahwa tenaga pengajar merupakan tenaga pendidik yang khusus diangkat dengan tugas utama mengajar, pada jenjang pendidikan dasar dan menengah disebut guru dan pada jenjang pendidikan tinggi disebut dosen. Jadi yang dimaksud dengan guru adalah seseorang yang pekerjaannya atau profesinya mengajar di sekolah jenjang pendidikan tingkat dasar dan tingkat menengah.

Hakikat tugas utama tugas seorang guru adalah merencanakan, mengelola, menilai proses pembelajaran yang di dalamnya terdapat berbagai kegiatan memilih, menilai dan mengambil keputusan profesional (Soedijarto, 2008). Kinerja guru yang baik terlihat dari hasil yang diperoleh dari penilaian prestasi belajar siswa (Glasman, 1986). Demikian juga Indikator kinerja guru dapat terlihat juga dalam kepuasaan siswa dan orang tua, perilaku sosial dan kehadiran guru.

Berdasarkan penjelasan tersebut di atas, kinerja guru dalam bidang pendidikan adalah produk jasa, prestasi kerja, hasil kerja, kemampuan kerja yang dicapai oleh seorang guru pada waktu tertentu dalam melaksanakan tugas sesuai dengan tanggung jawab yang diberikan kepadanya, yaitu sebagai pendidik, pengajar, dan pelatih terhadap peserta didik.

9 | Almarhalah | Jurnal Pendidikan Islam 
Secara garis besar ruang lingkup kinerja guru meliputi; perencanaan pengajaran, pengelolaan kelas, pembelajaran, dan mengadakan evaluasi (Stufflebeam, 1972). Sedangkan aspek-aspek dapat yang dinilai dalam kinerja guru adalah sebagai berikut :

a. Kemampuan professional, mencakup: Penguasaan pelajaran yang terdiri atas penguasaan bahan yang harus diajarkan dan konsep-konsep dasar keilmuan dan bahan yang diajarkan, Penguasaan dan penghayatan atas landasan dan wawasan kependidikan dan keguruan, dan Penguasaan prosesproses kependidikan keguruan dan pembelajaran siswa.

b. Kemampuan sosial, mencakup kemampuan untuk menyesuaikan diri dengan tuntutan kerja dan lingkungan sekitar waktu membawakan tugasnya sebagai guru.

c. Kemampuan personal guru, mencakup: Penampilan sikap guru yang positif terhadap keseluruhan tugasnya sebagai guru dan terhadap keseluruhan situasi pendidikan beserta unsur-unsurnya, Pemahaman, penghayatan dan penampilan nilai-nilai yang seyogyanya dianut oleh seorang guru.

d. Keperibadian, mencakup: nilai, sikap hidup, penampilan dan upaya untuk menjadikan dirinya sebagai panutan dan teladan bagi para siswa (Idochi, 2003).

Model yang menjelaskan tentang indikator kinerja yang digunakan untuk aktifitas yang hanya ditetapkan secara kualitatif atas dasar perilaku yang dapat diamati, yaitu menunjuk kepada beberapa aspek kinerja yang perlu diobservasi, meliputi motif, alat atau sarana, kompetensi, peluang, standar, umpan balik, dan tujuan.

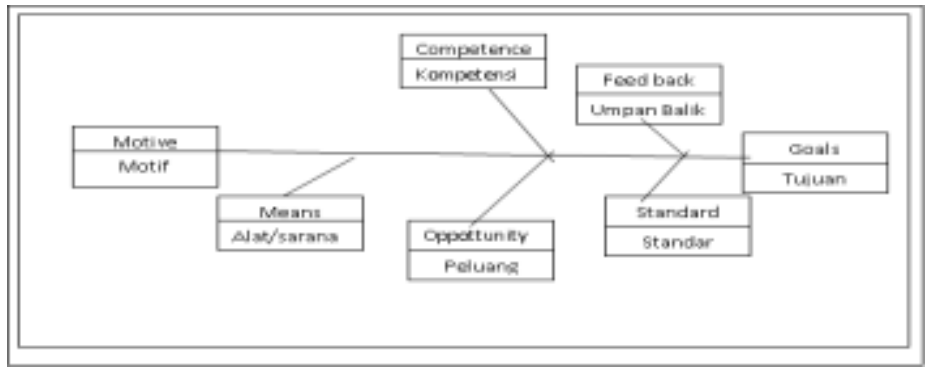

Hersey Model (Paul Hersey 1996:)

Sementara itu, faktor-faktor yang dapat mempengaruhi kinerja guru dalam mencapai tujuan pendidikan meliputi; 1) Faktor internal, yaitu faktor-faktor yang ada dalam diri guru yang bersangkutan yang tentu sangat berpengaruh terhadap usaha guru tersebut dalam mencapai tujuan yang telah ditetapkan, seperti; wawasan dan kemampuan professional, sikap mental, pengalaman lapangan dan kerjasama dan 2) Faktor eksternal, yaitu faktor-faktor yang berada diluar diri individu seorang guru, di antaranya meliputi: sarana prasarana (operasional kurikulum, buku panduan guru, buku pegangan siswa, dan buku-buku penunjang lainnya), lingkungan sekolah atau madrasah, pengawasan (pengawasan yang dilakukan oleh kepala madrasah dan pengawasan fungsional yang dilakukan oleh Departemen Agama) dan kesejahteraan guru (gaji, insentif, dan berbagai tunjangan dan reward lainnya) (Paraba, 2000).

10 | Almarhalah I Jurnal Pendidikan Islam 
Dalam penjelasan lainnya, faktor-faktor yang mempengaruhi kinerja pegawai meliputi faktor kemampuan dan faktor motivasi (Mangkunegara, 2002). Rosyada (2004) berpendapat secara umum kinerja guru harus memenuhi dua kategori, yaitu memiliki capability dan loyality, yakni seorang guru harus memiliki kemampuan dalam bidang ilmu yang diajarkannya dari mulai perencanaan, implementasi sampai evaluasi, dan memiliki loyalitas keguruan, ialah loyalitas terhadap tugas-tugas keguruan yang tidak semata di kelas, tapi sebelum dan sesudah di kelas.

Kinerja dalam pandangan Islam, bahwa seorang guru dalam melaksanakan kegiatan pembelajaran haruslah dikerjakan dengan baik, sebagai konsekwensi dari pekerjaannya sebagai seorang guru, bukan karena ingin mendapatkan penilaian dari atasannya. Karena pelaksanaan kewajiban itu tidak hanya di pertanggung jawabkan di dunia juga di akhirat. Hal ini sebagaimana firman Allah SWT, yaitu :

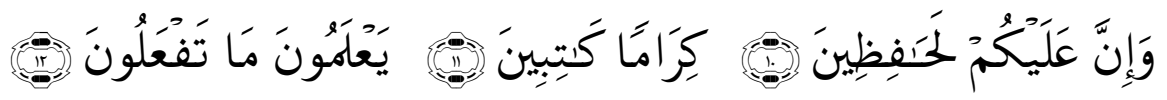

Artinya: "Padahal sesungguhnya bagi kamu ada (malaikat-malaikat) yang mengawasi (pekerjaanmu), Yang mulia (di sisi Allah) dan mencatat (pekerjaan-pekerjaanmu itu), Mereka mengetahui apa yang kamu kerjakan”. (QS. Al-Infithaar:10-12).

\section{METODE}

\section{Lokasi dan Waktu Penelitian}

Penelitian ini dilakukan pada Madrasah Tsanawiyah (MTs) yang berada di Kabupaten Pandeglang. Sedangkan waktu penelitian ini yaitu bulan Juli sampai dengan bulan Desember 2020.

\section{Metode}

Metode penelitian ini menggunakan metode survey dengan menggunakan teknik analisis korelasional. Metode ini memberi gambaran tentang variabelvariabel yang ditemukan, sekaligus menyelidiki hubungan antara variable. Oleh karena itu metode ini akan mengungkapkan data faktual berdasarkan informasi yang ditemukan. Sedangkan analisis korelasi digunakan untuk mengetahui yaitu: 1) Hubungan antara pasangan skor variabel motivasi kerja dengan kinerja guru,, 2) Hubungan antara pasangan skor variabel kemampuan penguasaan materi dengan kinerja guru dan 3) Hubungan antara pasangan skor variabel motivasi kerja dan kemampuan penguasaan materi secara bersama-sama terhadap variabel kinerja guru.

\section{Teknik Pengambilan Sampel}

Populasi dalam penelitian ini adalah seluruh guru pada Bidang Studi Akidah Akhlak pada Madrasah Tsanaawiyah (MTs) di Kabupaten Pandeglang Banten Tahun 2020 yang berjumlah 175 guru. Teknik pengambilan sampel dalam penelitian ini menggunakan random sampling. Berdasarkan populasi tersebut, maka jumlah sampel yang digunakan dalam penelitian ini sebanyak 35 guru atau sebesar 20\% dari jumlah populasi sebesar 175 guru.

\section{Teknik Pengumpulan Data}

11 | Almarhalah | Jurnal Pendidikan Islam 
Pengumpulan data dalam penelitian ini yaitu; 1) Kuesioner, yaitu daftar yang berisi pertanyaan/pernyataan yang tertulis yang diberikan kepada responden yang bertujuan untuk memperoleh data variabel motivasi kerja dan kinerja guru, 2) Tes, yaitu berisi soal-soal pertanyaan pilihan ganda tentang materi bidang studi Aqidah Akhlak, bertujuan untuk memperoleh data kemampuan guru dalam penguasaan materi bidang studi Aqidah Akhlak, 3) Observasi, yaitu pengamatan secara langsung ke lokasi penelitian untuk mendapatkan data dokumen yang berkaitan dengan penelitian ini dan 4) Wawancara, yaitu melakukan tanya jawab dengan sumber data, yang bertujuan untuk memperoleh data tentang aktivitas proses belajar mengajar terhadap siswa di sekolah, dan untuk mengetahui tentang implementasi visi dan misi madrasah serta permasalahan lain yang ada di madrasah tersebut.

\section{Instrumen Penelitian}

Variabel motivasi kerja dan kinerja guru dalam penelitian ini menggunakan model skala Likert yang terdiri dari lima pilihan, yaitu Selalu, Sering, Kadang-kadang, Pernah dan Tidak Pernah. Masing-masing pertanyaan atau pernyataan diberi skor 1 sampai 5 . Variabel kemampuan penguasaan materi disusun dalam bentuk soal tes, dengan dua alternatif jawaban, yaitu skor tertinggi ke skor yang terrendah. Untuk pertanyaan yang benar diberi skor 1 (satu). Untuk menjaga keseimbangan hubungan dengan variabel lainnya maka nilai skor 1 dikonversi menjadi nilai skor 2 tiap butirnya. Sebaliknya untuk pertanyaan yang salah mempunyai skor 0 (nol).

Variabel-variabel yang akan diteliti secara konseptual operasional dapat didefinisikan sebagai berikut :

a. Motivasi Kerja Guru $\left(\mathrm{X}_{1}\right)$

Definisi Konseptual: Motivasi kerja guru adalah suatu proses yang dilakukan untuk menggerakan guru agar perilakunya dapat di arahkan pada upaya-upaya yang nyata untuk mencapai tujuan yang telah ditetapkan, sehingga dalam melaksanakan tugasnya guru tersebut bertanggung jawab, berprestasi, dapat mengembangkan dirinya, dan dapat mandiri dalam melakukan tindakan dalam proses belajar mengajar.

Definisi Operasional: Motivasi kerja guru adalah skor yang diperoleh guru tentang suatu proses yang dilakukan untuk menggerakan guru agar perilakunya dapat di arahkan pada upaya-upaya yang nyata untuk mencapai tujuan yang telah ditetapkan, sehingga dalam melaksanakan tugasnya guru tersebut bertanggung jawab, berprestasi, dapat mengembangkan dirinya, dan dapat mandiri dalam melakukan tindakan dalam proses belajar mengajar.

b. Kemampuan Penguasaan Materi $\left(\mathrm{X}_{2}\right)$

Definisi Konseptual: Kemampuan penguasaan materi adalah suatu kesanggupan, kecakapan, keterampilan dan kekuatan dari seorang guru dalam menguasai materi atau bahan ajar pada bidang studi yang menjadi tanggung jawabnya dalam proses belajar mengajar terhadap siswanya di dalam kelas.

Definisi Operasional: Kemampuan penguasaan materi adalah skor yang diperoleh tentang suatu kesanggupan, kecakapan, keterampilan dan kekuatan dari seorang guru dalam menguasai materi atau bahan ajar pada bidang studi yang

12 | Almarhalah | Jurnal Pendidikan Islam 
menjadi tanggung jawabnya dalam proses belajar mengajar terhadap siswanya di dalam kelas.

c. Kinerja Guru (Y)

Definisi Konseptual: Kinerja guru adalah merupakan gambaran dari kemampuan hasil kerja atau prestasi kerja yang dihasilkan guru dalam melaksanakan tugasnya yaitu melaksanakan perencanaan pengajaran, mengelola kelas, melaksanakan program pengajaran, dan melakukan evaluasi hasil belajar siswa yang merupakan tanggung jawabnya.

Definisi Operasional: Kinerja Guru adalah skor tentang gambaran dari kemampuan hasil kerja atau prestasi kerja yang dihasilkan guru dalam melaksanakan tugasnya yaitu melaksanakan perencanaan pengajaran, mengelola kelas, melaksanakan program pengajaran, dan melakukan evaluasi hasil belajar siswa yang merupakan tanggung jawabnya.

d. Analisis Data

Analisis data dalam penelitian ini yaitu pertama: Uji Persayaratan Analisis dilakukan meliputi; Uji Normalitas, Homogenitas dan Linearitas dan Kedua: Pengujian Hipotesis, meliputi; Korelasi Antar Variabel, Regresi Sederhana Korelasi Ganda dan Regresi Ganda (Multiple).

Pengujian hipotesis penelitian dilakukan sesuai dengan langkah-langkah, yaitu; Pertama: Pengujian hipotesis satu dan dua menggunakan korelasi product moment. Pengujian ini dilakukan untuk menghitung koefisien korelasi antara masing-masing variabel bebas dengan variabel terikat sebagai syarat untuk menghitung besarnya koefisien determinasi. Penghitungan ini kemudian dilanjutkan dengan menghitung persamaan regresi untuk masing-masing variabel bebas atau variabel terikat. Kedua: Pengujian hipotesis tiga dilakukan dengan menggunakan korelasi ganda dengan maksud untuk menentukan besarnya koefisien korelasi ganda dari kedua variabel bebas atas variabel terikat, demikian juga untuk menentukan besarnya koefisien determinasi kedua variabel bebas atas variabel terikat.

\section{HASIL PEMBAHASAN}

\section{Hubungan antara Motivasi Kerja dengan Kinerja}

Hasil pengujian hipotesis pertama membuktikan bahwa motivasi kerja mempunyai hubungan positif dengan kinerja guru. Koefisien korelasi motivasi kerja dengan kinerja guru sebesar $r_{\mathrm{y} 1}=0.881$. Koefisien determinasi koefisien korelasi antara motivasi kerja dengan kinerja guru sebesar $=(0,881)^{2}=0,777$ atau $77,70 \%$, artinya bahwa sekitar $=77,70 \%$ variasi yang terjadi pada kinerja guru dapat dijelaskan oleh motivasi kerja.

Hubungan motivasi kerja dengan kinerja guru mempunyai persamaan regresi $\hat{Y}=12,634+0,674 \mathrm{x}_{1}$. Hal ini berarti dapat diketahui bahwa makin tinggi motivasi kerja, maka akan semakin tinggi pula kinerja guru. Peningkatan satu skor pada motivasi kerja menyebabkan peningkatan $=0,674$ skor kinerja guru pada konstanta=12,634. Seorang guru yang memiliki motivasi kerja yang baik akan mendukung terjadinya kinerja guru yang baik pula, sehingga dapat meningkatkan kinerja guru. Hal ini sebagaimana dijelaskan pada tabel di bawah ini: 
Tabel 1.

Koefisien Korelasi antara Motivasi Kerja dengan Kinerja Guru

\begin{tabular}{|c|c|c|c|c|c|}
\hline Korelasi & $\mathbf{N}$ & $\mathbf{R}$ & $\mathbf{r}^{\mathbf{2}}$ & $\mathbf{t}_{\text {hitung }}$ & $\mathbf{t}_{\text {tabel }}(\boldsymbol{\alpha}=\mathbf{0 , 0 5})$ \\
\hline $\mathrm{r}_{\mathrm{v} 1}$ & 35 & 0,881 & 0,777 & $10,721 * *$ & 1,690 \\
\hline $\begin{array}{c}\mathrm{r}_{\mathrm{y} 1} \\
\left(\text { dikontrol } \mathrm{X}_{2} \text { ) }\right.\end{array}$ & 35 & 0,406 & 0,165 & $2,508 * *$ & 1,690 \\
\hline
\end{tabular}

Gambar 1

Diagram garis Regresi Linear $\hat{Y}=12,634+0,674 X_{1}$

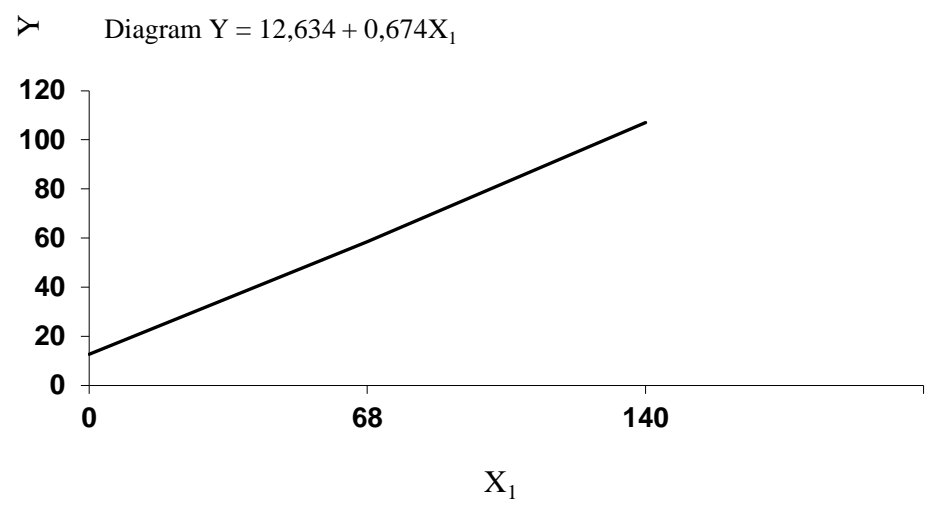

Tabel 2.

Analisis Varian untuk Uji Signifikansi

Persamaan Regresi $\hat{Y}=12,634+0,674 X_{1}$

ANOVA $^{\mathrm{b}}$

\begin{tabular}{|l|r|r|r|r|r|}
\hline \multicolumn{1}{|c|}{ Model } & Sum of Squares & df & Mean Square & F & Sig. \\
\hline 1 Regression & 6739.686 & 1 & 6739.686 & 114.947 & $.000^{\mathrm{a}}$ \\
Residual & 1934.886 & 33 & 58.633 & & \\
Total & 8674.571 & 34 & & & \\
\hline
\end{tabular}

A. Predictors: (constant), motivasi kerja

B. Dependent variable: kinerja guru

\section{Hubungan Kemampuan Penguasaan Materi dengan Kinerja Guru}

Hasil pengujian hipotesis kedua membuktikan bahwa kemampuan penguasaan materi mempunyai hubungan positif dengan kinerja guru. Koefisien korelasi kemampuan penguasaan materi dengan kinerja guru sebesar $r_{\mathrm{y} 2}=0,857$. Koefisien determinasi koefisien korelasi antara kemampuan penguasaan materi dengan kinerja guru sebesar $=(0,857)^{2}=0,735$, artinya bahwa sekitar $=73,50 \%$ variasi yang terjadi pada kinerja guru dapat dijelaskan oleh kemampuan penguasaan materi.

Hubungan kemampuan penguasaan materi dengan kinerja guru mempunyai persamaan regresi $\mathrm{Y}^{\prime}=6,998+1,116 \mathrm{X}_{2}$. Hal ini berarti dapat diketahui bahwa makin tinggi kemampuan penguasaan materi, maka akan semakin tinggi pula kinerja guru. Peningkatan satu skor pada kemampuan 
penguasaan materi menyebabkan peningkatan $=1,116$ skor kinerja guru pada konstanta $=6,998$. Seorang guru yang memiliki kemampuan penguasaan materi yang baik akan mendukung terjadinya kinerja guru yang baik pula, sehingga dapat meningkatkan kinerja guru. Hal ini sebagaimana dijelaskan pada tabel di bawah ini:

Tabel 3.

Koefisien Korelasi antara kemampuan penguasaan materi dengan Kinerja Guru

\begin{tabular}{|c|c|c|c|c|c|}
\hline Korelasi & $\mathrm{N}$ & $\mathrm{R}$ & $\mathrm{r}^{2}$ & $\mathrm{t}_{\text {hitung }}$ & $\begin{array}{c}\mathrm{t}_{\text {tabel }} \\
(\alpha=0,05)\end{array}$ \\
\hline $\mathrm{r}_{\mathrm{y} 2}$ & 35 & 0,857 & 0,735 & $9,569^{* *}$ & 1,690 \\
\hline $\mathrm{r}_{\mathrm{y} 2}\left(\right.$ dikontrol $\left.\mathrm{X}_{1}\right)$ & 35 & 0,089 & 0,0079 & $0,507^{\text {ns }}$ & 1,690 \\
\hline
\end{tabular}

Gambar 2

Diagram garis Regresi Linear $Y=6,998+1,116 \mathrm{X}_{2}$

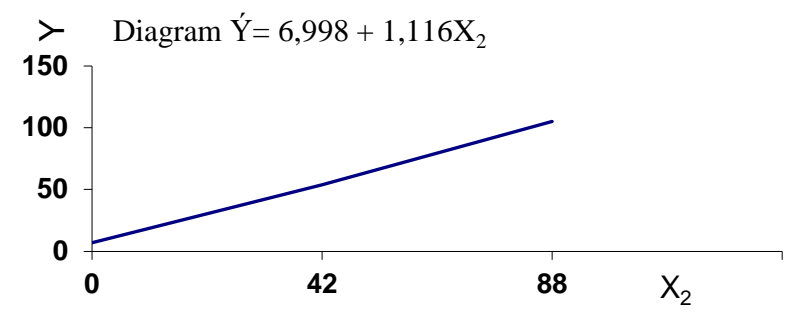

Tabel 4.

Analisis Varian untuk Uji Signifikans

Persamaan Regresi Y' = 6,998 + 1,116X2

\begin{tabular}{|c|c|c|c|c|c|c|}
\hline \multicolumn{7}{|c|}{ ANOVA $^{b}$} \\
\hline \multicolumn{2}{|c|}{ Model } & Sum of Squares & Df & Mean Square & $\mathrm{F}$ & Sig. \\
\hline & Regression & 6376.660 & 1 & 6376.660 & 91.574 & $.000^{\mathrm{a}}$ \\
\hline & Residual & 2297.911 & 33 & 69.634 & & \\
\hline & Total & 8674.571 & 34 & & & \\
\hline
\end{tabular}

A. Predictors: (constant), kemampuan penguasaan materi

B. Dependent variable: kinerja guru

\section{Hubungan Motivasi Kerja dan Kemampuan Peguasaan Materi dengan Kinerja Guru}

Hasil pengujian hipotesis ketiga membuktikan bahwa motivasi kerja dan kemampuan penguasaan materi mempunyai hubungan positif dengan kinerja guru. Koefisien korelasi ganda motivasi kerja dan kemampuan penguasaan materi dengan kinerja guru sebesar $r_{\mathrm{y} 12}=0.882$. Koefisien determinasi koefisien korelasi antara motivasi kerja dan kemampuan penguasaan materi dengan kinerja guru sebesar $=(0,882)^{2}=0,779$ atau 77,90\%, artinya bahwa sekitar $=77,90 \%$ variasi yang terjadi pada kinerja guru dapat dijelaskan oleh motivasi kerja dan 
kemampauan penguasaan materi, sedangkan sisanya sebesar $=22.10 \%$ dijelaskan oleh faktor lain yang tidak dibahas dalam penelitian ini.

Hubungan motivasi kerja dan kemampuan penguasaan materi dengan kinerja guru mempunyai persamaan regresi $\hat{Y}=14,878+0,839 \mathrm{X}_{1}-0,286 \mathrm{X}_{2}$. Hal ini berarti dapat diketahui bahwa makin tinggi motivasi kerja dan kemampuan penguasaan materi maka akan semakin tinggi pula kinerja guru. Peningkatan satu skor pada motivasi kerja dan kemampuan penguasaan materi menyebabkan peningkatan $=0,286$ skor kinerja guru pada konstanta $=14,878$. Seorang guru yang memiliki motivasi kerja dan kemampuan penguasaan materi yang baik akan mendukung terjadinya kinerja guru yang baik pula, sehingga dapat meningkatkan kinerja guru. Hal ini sebagaimana dijelaskan pada tabel di bawah ini:

Tabel 5.

Koefisien Korelasi ganda antara Motivasi Kerja dan Kemampuan Penguasaan Materi dengan Kinerja Guru

Analisis Variansi Regresi Linear Ganda

ANOVA $^{\mathrm{b}}$

\begin{tabular}{|l|l|r|c|r|r|l|}
\hline \multicolumn{2}{|c|}{ Model } & Sum of Squares & df & Mean Square & F & Sig. \\
\hline \multirow{3}{*}{1} & Regression & 6754.896 & 2 & 3377.448 & 56.300 & $.000^{\text {a }}$ \\
\cline { 2 - 8 } & Residual & 1919.675 & 32 & 59.990 & & \\
\cline { 2 - 8 } & Total & 8674.571 & 34 & & & \\
\hline
\end{tabular}

a. Predictors: (constant), motivasi kerja, kemampuan penguasaan materi

b. Dependent variable: kinerja guru

\section{Pembahasan}

Dari hasil penelitian ditemukan beberapa informasi bahwa guru yang memiliki kinerja harus didukung oleh motivasi kerja dan kemampuan penguasaan materi. Oleh karenanya dengan motivasi kerja dan kemampuan penguasaan materi yang baik, maka guru akan memiliki kinerja yang baik pula. Untuk dapat memiliki kinerja guru yang baik, maka dibutuhkan motivasi kerja dan juga kemampuan penguasaan materi yang dimiliki oleh guru. sebaliknya kinerja guru akan menurun apabila tidak didukung oleh motivasi kerja dan kemampuan penguasaan materi yang dimiliki oleh guru tersebut.

Berdasarkan hasil perhitungan statistik bahwa motivasi kerja memberikan kontribusi sebesar 77,70 \% terhadap kinerja guru. Dengan demikian adanya faktor kerja keras, tanggung jawab, pencapaian tujuan, menyatu dengan tugas, dorongan untuk sukses, umpan balik dan unggul, peningkatan keterampilan, dorongan untuk maju, mandiri dalam bekerja dan suka pada tantangan sangat berpengaruh terhadap peningkatan kinerja guru. Sedangkan kemampuan penguasan materi memberikan kontribusi sebesar 73,50 \% terhadap kinerja guru, hal ini artinya bahwa indikator kemampuan penguasaan materi bidang studi Aqidah Akhlak yaitu mampu menjelaskan : tentang Malaikat dan Nabi SAW, tentang sifat-sifat Allah, tentang rukun iman, tentang al-Qur'an, tentang hari akhir, berakhlak baik kepada Allah, kepada manusia, kepada alam sekitarnya, mempraktekkan iman kepada Allah SWT, memprakktekan akhlak kepada sesama dan mampu

16 | Almarhalah | Jurnal Pendidikan Islam 
mempraktekan akhlak kepada alam, sangat berpengaruh terhadap kinerja guru. Sementara itu, motivasi kerja dan kemampuan penguasaan materi secara bersamasama dapat memberikan kontribusi terhadap kinerja guru sebesar 77,90\%, sedangkan sisanya $22,1 \%$ belum dapat dijelaskan, dalam arti berasal dari variabel lain yang tidak turut diungkapkan dalam penelitian ini, seperti; kepemimpinan, lingkungan kerja, disiplin kerja, budaya organisasi, minat kerja, penghargaan dan lain-lain.

\section{KESIMPULAN}

Hasil temuan penelitian ini dapat disimpulkan adalah sebagai berikut :

1. Terdapat hubungan antara motivasi kerja dengan kinerja guru dengan koefisien korelasi sebesar 0,881 , artinya hubunganya positif dan sifnifikan Dengan kata lain, bahwa motivasi kerja memberikan dukungan positif atau kontribusi terhadap kinerja guru, atau motivasi kerja merupakan salah satu faktor yang harus diperhatikan untuk meningkatkan kinerja guru. Motivasi kerja yang meningkatkan dengan kinerja guru yaitu kerja keras, tanggung jawab, pencapaian tujuan, menyatu dengan tugas, dorongan untuk sukses, umpan balik dan unggul, peningkatan keterampilan, dorongan untuk maju, mandiri dalam bekerja dan suka pada tantangan.

2. Terdapat hubungan antara kemampuan penguasaan materi dengan kinerja guru dengan koefisien korelasi sebesar 0,857, artinya hubungannya positif dan signifikan. Dengan kata lain, bahwa kemampuan penguasaan materi memberikan dukungan positif atau kontribusi terhadap kinerja guru, atau bahwa kemampuan penguasaan materi merupakan salah satu faktor yang harus diperhatikan untuk meningkatkan kinerja guru. Kemampuan penguasaan materi bahan ajar yang dapat meningkatkan kinerja guru yaitu kemampuan kognitif, afektif dan psikomotorik.

3. Terdapat hubungan antara motivasi kerja dan kemampuan penguasaan materi secara bersama-sama dengan kinerja guru dengan koefisien korelasi sebesar 0,882, artinya hubungannya positif dan signifikan. Dengan kata lain, bahwa motivasi kerja dan kemampuan penguasaan materi secara bersama-sama memberikan dukungan positif atau kontribusi terhadap kinerja guru. Indikator kinerja guru yang dapat ditingkatkan oleh motivasi kerja dan kemampuan pengusaan materi bahan ajar yaitu perencanaan pengajaran, mengelola kelas, program pembelajaran dan evaluasi hasil belajar. Sementara itu, faktor lain yang berhubungan dengan kinerja guru yaitu kepemimpinan, lingkungan kerja, disiplin kerja, budaya organisasi, minat kerja, penghargaan dan lain-lain yang tidak diterangkan dalam penelitian ini.

\section{SARAN-SARAN}

Saran-saran terkait hasil penelitian ini yang dapat peneliti kemukakan adalah sebagai berikut:

1. Bahwa untuk menumbuhkan, mengembangkan, meningkatkan dan memelihara motivasi kerja walaupun dititikberatkan kepada usaha 
maksimal dari individu guru, tapi sangat dibutuhkan keterlibatan dan komitmen semua pihak, baik dari komponen penyelenggara maupun pengelola pendidikan untuk memfasilitasi berbagai sumber yang berkaitan dengan kelancaran proses belajar mengajar sehingga faktor-faktor yang mempengaruhi timbulnya motivasi kerja tercapai. Sehingga apabila motivasi kerja guru baik, maka dengan sendirinya akan meningkatkan kinerja guru itu sendiri.

2. Dalam Undang-undang Guru dan Dosen Nomor 14 Tahun 2005 dijelaskan bahwa kemampuan penguasaan materi adalah termasuk kompetensi profesional yang merupakan salah salah satu kompetensi guru.Untuk menjalankan profesinya sebagai seorang guru yang professional, maka guru harus memperoleh penghasilan dan kebutuhan hidup yang layak. Di samping itu, untuk tercapainya kemampuan penguasaan materi oleh individu guru dengan baik, maka perlu dilakukan juga berbagai upaya dari pihak sekolah untuk menyediakan berbagai fasilitas sarana dan prasarana yang berkaitan denga pembelajaran di sekolah. Sehingga dengan adanya fasilitas yang memadai yang dapat diakses oleh guru dalam menjalankan proses belajar mengajar, maka akan meningkatkan kinerja guru yang optimal.

3. Untuk meningkatkan dan memelihara kinerja guru dalam menjalankan proses belajar mengajar, maka salah satu kata kuncinya adalah adanya pemenuhan terhadap faktor-faktor timbulnya motivasi kerja dan kemampuan penguasaan materi oleh individu guru. Oleh karena itu, untuk tercapainya motivasi kerja dan kemampuan penguasaan materi oleh individu guru dengan baik, maka perlu dilakukan juga berbagai upaya maksimal dari semua pihak penyelenggara dan pengelola pendidikan untuk mengadakan perlindungan kepada guru yang meliputi penegakan hak dan kewajiban, pembinaan dan pengembangan karir, perlindungan hukum, perlindungan profesi serta perlindungan keselamatan dan kesehatan kerja. Dengan adanya penegakkan hak dan kewajiban terahadap guru tersebut, niscaya akan menghasilkan bukan saja kerja guru akan tetapi kinerja atau prestasi guru dalam menjalankan proses belajar mengajar di sekolah.

4. Bagi penyelenggara dan pengelola pendidikan di Madrasah Tsanawiyah Kabupaten Pandeglang Banten, hendaknya senantiasa selalu berupaya untuk terus menerus meningkatkan kondisi kondusif dan konstruktif dalam lingkungan sekolah demi tercapainya proses belajar mengajar dengan baik. Demikian juga, harus selalu diupayakan dan dirangsang untuk tumbuh dan berkembangnya faktor-faktor yang mempengaruhi timbulnya motivasi kerja dan kemampuan penguasaan materi oleh individu guru, agar kinerja guru di sekolah tersebut dapat tercapai. 


\section{DAFTAR PUSTAKA}

Adi, Isbandi Rukminto, 2004. Psychology, Social Work and Social Welfare: Fundamentals of Thought, Jakarta: Grafindo Persada.

Anoraga, Panji, 2002. Work Psychology, Jakarta: Rineka Cipta

Atmowidjoyo, Sutardjo, 2009. Instructional System Design, Jakarta: Universitas Islam Jakarta.

Atkinson, Rita L and Richard C Ernest R. Hilgard, 1983. Introduction to Psychology, California, Harcout Brace Javanovich

Arikunto, Suharsimi, 2016. Procedure of Scientific Research, Jakarta: Bina Aksara.

As'ad, Moh. 2000, Industrial psychology, Yogyakarta: Liberty.

Adikoesoemo, Suparto, 2002. Hospital Management, Jakarta: Sinar Harapan.

Arifin, Muhamad, 2000. Capita Selecta Islamic Education, Jakarta: Bumi Aksara.

Bernadin,John H and Russel, 1995. Joyce, Human Resource Managemen an Experitial Aproach, New York: MC. Grouw Hill

Chimajah, Noor, 2000. Role of Work Motivation to Work Productivity, Majalah Ilmiah Widya, No. 150 Bulan Maret.

Cooper. 2009. Kompetensi Profesional Seorang Guru. Tersedia; http://inboxkita.blogspot.com/2013/06/kompetensi-profesional- seorangguru-dan.html. diakses 18 Oktober 2013

Dharma, Agus, 2005. Job Performance Management, Jakarta: Rajawali.

Davis, Keith and John W. Newstrom, 1995. Organizational Behavior, translation, Agus Dharma, Jakarta: Erlangga.

Denny, Richard, 1995. Motivating Success: Kick-Ass Improve Performance, Jakarta: Gramedia Pustaka Utama.

Djatmiko, Yayat Hayati, 2002. Organizational Behavior, Bandung: Alfabeta.

Fattah, Nanang, 2001. Education Management Runway, Bandung: Remaja Rosdakarya.

French, L. Wendel, 1986. Human Resource Management, Houstan Dallas: Houghon Mifflin Company.

Flippo, Edwin B, 2007. Personnel Management, Translation, Moh. Ma'ud, Jakarta: Erlangga.

Ferguson, George, 1989. Statistical Analysis in Psycholoy and Education, New York: McGrwa-Hill Book Company.

Gomes, F. Cardoso, 2007. Human Resource Management, Yogyakarta: Andi Offset.

Gibson, Ivancevich dan Weihrich , 1997. Organization, Volume 1, terjemah, Djarkasih, Jakarta: Erlangga

Gerungan, WA, 2003, Social Psycology, Bandung: Eresco.

Good, Thomas L, and Brophy, Jere E, 1990. Educational Psychology, A Realistic Appoach, New York: Longman

Hoy, Wayne K. and Cecil G. Miskel, 1978. Education Administration Theory, Research and Practice, New York: Random House, Inc. 
Hugh J. Arnold and Daniel C. Feldman, 1986. Organizational Behavior, New York: McGraw-Hill Book Company.

Hoogendoorn, J.1989, Providing Leadership in Cooperation, Jakarta: UI Press.

Hadari, Nawawi, 2003. Strategic Management of Non Profit Organizations Government Sector, Yogyakarta: Gajah Mada Unversity Press Gunung Agung. , 2005. School Organization and Management Class, Jakarta:

Hamalik, Oemar, 2005. Teaching and learning process, Jakarta: Bumi Aksara

Hellriegel, Don and John W. Slocum, Jr, 1979. Organizational Behavior, New York

Handoko, Hani, 2005. Management, Yogyakarta: BPFE

Idochi , Anwar M, 2003. Educational Administration and Management Education Costs, Bandung: Alfabeta

JP. Guilford, 1965. Fundamental Statistic in Psychology and Education, New York, Mc Graw-Hill Book Company

Jumantoro, Totok, 2001. Psychology of Da'wa (with aspects of the Qur'anic Psycho), Surabaya: Hamzah

Koontz, Harold, Cryril O’Donnel dan Heihrich Weihrich, 1993. Management, translation, Antarikso dkk, Jilid II, Jakarta: Erlangga.

Keith, Davis and John W. Newstrom, Organizational Behavior, translation, Agus Dharma, Jakarta: Erlangga, 1993.

Komarudin, 2002. Encyclopedia of Management, Jakarta: Bumi Aksara.

Lucio, William H dan John D. McNeil, 1979. Supervision: A Synthesis of Thought and Action, New York: Mc Graw-Hill Book Company

Mulyasa, E. 2002, Competency-Based Curriculum, Bandung, Remaja Rosdakarya , 2003. School-Based Management: Concepts, Strategies and Implementation, Bandung: Remaja Rosdakarya.

Moenir, HAS, 2001. Management of Public Services in Indonesia, Jakarta: Bumi Aksara.

Martoyo, Susilo, 2000. Human Resource Management, Yogyakarta: BPFE.

Musri, Abdul Hamid,2001. Productive Human Resources, approach the Qur'an and Science, Jakarta: Gema Insani Press.

N. Kerlinger, Pred, 1973. Fundations of Research, New York Holt: Rinehart and Winston, Inc,.

Purwanto, Ngalim, 2007. Educational psychology, Bandung: Remaja Rosdakarya. , 2007. Educational Administration and Supervision. Bandung: Remaja Rosdakarya.

Paraba, Hadirja, 2000. Insights Tasks Teachers and coaches Islamic Education, Jakarta: Friska Agung Insani

Pace, R. Wayne, and Don F. and Faules, 2001. Organizational Communication: Strategies Improve Corporate Performance, terjemahan Edi Mulyana, Bandung: Remaja Rosdakarya.

Ruky, Ahmad S, 2002.Performance Management System, Jakarta: Gramedia.

Robbins, Stephen P, 1986. Organizational Behavior, Concept, Controversies and Application, New Jersey: Prentice-Hill.

20 | Almarhalah | Jurnal Pendidikan Islam 
Robbins, Stephen P dan Mary Coulter, 1999, Management, translation, T. Hermaya, Jilid 2, Jakarta: Prenhallindo

Rosyada, Dede, 2004. Paradigm Democratic Education; A Model Community Involvement in Education Implementation, Jakarta: Kencana

Robert, C. Beck, 1990. Motivation Theoritis and Principle, New Jersey: PrenticeHall, Englewood Cliffs

Stoner, James A.F., R. Edward Freeman dan Daniel R Gilbert, JR, 1996.Management, translation, Alexander Sindoro, Jakarta:Prenhallindo.

Sopyan, Herminarto dan Hamzah M. Uno, 2004. Motivation Theory and Its Application in Research, Gorontalo, Nurul Jannah.

Simamora, Henry, 2005. Human Resource Management, Yogyakarta: STIE YKPN, 1995.

Sastrohadiwirjo, Siswanto, 2002. Workforce Management Indonesia, Jakarta: Bumi Aksara.

Simanjuntak, 2003. Education as a Means of Mental Reform in Nation-Building Efforts, Jakarta: Balai Pustaka.

Sardiman, AM. 2008., Interaction and Learning Motivation, Jakarta: Rajawali.

Sudjana, 2002. Regression and Correlation Analysis Techniques for Researchers, Bandung:Tarsito,. 2002. Statistical Methods, Bandung: Tarsito

Sidi, Indra Jati, 2001. To community Learning, Jakarta: Logos Wacana Ilmu.

Siagian, Sondang P, 2005. Philosophy Administration, Jakarta: Gunung Agung. 2001.Growing Techniques and Maintaining Organizational Behavior, Jakarta: Haji Mas Agung. 2000. Motivation Theory and Its Application, Jakarta: Bumi Aksara.

Sukmadinata, Nana Syaodih, 2003. The cornerstone of Psychology Education Process, Bandung: Rosdakarya

Suwarto, FX, 2000. Organisational Behaviour, Yogyakarta: Atma Jaya

Sutisna, Oteng,2001. Administration Theoretical Basic Education for Professional Practice, Bandung: Angkasa

Soedijarto, 2008. Landasan dan Arah Pendidikan Nasional Kita. Jakarta : Kompas

Steers, Hackman, Lawler, Richard and Lyman, Porter, 1991. Motivation and Work Behavior, New York: McGraw-Hill, Inc,

Usman, Moh. Uzer, 2002. Become Teachers Proffesional, Bandung: Rosdakarya

Whitmore, John, 1997. Coaching for Performance: Seni Mengarahkan untuk Mendongkrak Kinerja, terjemahan Y Dwi Helly Purnomo, Jakarta: Gramedia Pustaka Utama.

Warkitri, dkk, 2001. Stabilization Teaching Ability, Jakarta: Pusat Penerbitan Universitas Terbuka

Wahjosumidjo, 2001. Leadership and Motivation, Jakarta: Ghalia Indonesia

William, B. Cassetter, 1996. The Human Rseource Function in Educational Administration, New Jersey

Winkel, WS. 2006. Teaching psychology, Jakarta:Grafindo 